\title{
Towards physiologically relevant human pluripotent stem cell (hPSC) models of Parkinson's disease
}

\author{
Elena Coccia ${ }^{1,2,3,4,5}$ and Tim Ahfeldt ${ }^{1,2,3,4,5^{*}}$ (D)
}

\begin{abstract}
The derivation of human embryonic stem cells followed by the discovery of induced pluripotent stem cells and leaps in genome editing approaches have continuously fueled enthusiasm for the development of new models of neurodegenerative diseases such as Parkinson's disease (PD). PD is characterized by the relative selective loss of dopaminergic neurons (DNs) in specific areas of substantia nigra pars compacta (SNpc). While degeneration in late stages can be widespread, there is stereotypic early degeneration of these uniquely vulnerable neurons. Various causes of selective vulnerability have been investigated but much remains unclear. Most studies have sought to identify cell autonomous properties of the most vulnerable neurons. However, recent findings from genetic studies and model systems have added to our understanding of non-cell autonomous contributions including regionalspecific neuro-immune interactions with astrocytes, resident or damage-activated microglia, neuro-glia cell metabolic interactions, involvement of endothelial cells, and damage to the vascular system. All of these contribute to specific vulnerability and, along with aging and environmental factors, might be integrated in a complex stressor-threshold model of neurodegeneration. In this forward-looking review, we synthesize recent advances in the field of PD modeling using human pluripotent stem cells, with an emphasis on organoid and complex coculture models of the nigrostriatal niche, with emerging CRISPR applications to edit or perturb expression of causal PD genes and associated risk factors, such as GBA, to understand the impact of these genes on relevant phenotypes.
\end{abstract}

Keywords: Neurodegenerative disease modeling, Human pluripotent stem cells (hPSCs), CRISPR, Parkinson's disease, GBA

\section{Limitations of PD models}

Parkinson's disease (PD) is a neurodegenerative disorder (Table 1) for which the exact pathogenesis is still unknown, and no disease-modifying treatment exists to date. It is therefore essential to refine research models to better understand the pathophysiology underlying the neuronal loss and to develop therapeutic strategies.

\footnotetext{
* Correspondence: tim.ahfeldt@mssm.edu

'Nash Family Department of Neuroscience, Icahn School of Medicine at Mount Sinai, New York 10029, NY, US

${ }^{2}$ Department of Neurology, Icahn School of Medicine at Mount Sinai, New York 10029, NY, US

Full list of author information is available at the end of the article
}

Postmortem studies of PD patients have laid the foundation of our understanding of pathological aspects of the disorder. These include the presence of Lewy bodies, inclusions primarily composed of aggregated $\alpha$-synuclein $(\alpha-s y n)$, regional vulnerability of dopaminergic neurons, and the impact of oxidative stress, inflammation, infections, and environmental toxins [10]. However, these studies are restricted by the rarity of brain samples, ethical limitations, the loss of the most vulnerable neurons, and the restricted temporal window in which to examine samples, which has hindered genetic and mechanistic studies.

\section{$\triangle B M C$}

(c) The Author(s). 2021 Open Access This article is licensed under a Creative Commons Attribution 4.0 International License, which permits use, sharing, adaptation, distribution and reproduction in any medium or format, as long as you give appropriate credit to the original author(s) and the source, provide a link to the Creative Commons licence, and indicate if changes were made. The images or other third party material in this article are included in the article's Creative Commons licence, unless indicated otherwise in a credit line to the material. If material is not included in the article's Creative Commons licence and your intended use is not permitted by statutory regulation or exceeds the permitted use, you will need to obtain permission directly from the copyright holder. To view a copy of this licence, visit http://creativecommons.org/licenses/by/4.0/ The Creative Commons Public Domain Dedication waiver (http://creativecommons.org/publicdomain/zero/1.0/) applies to the data made available in this article, unless otherwise stated in a credit line to the data. 
Table 1 Parkinson's disease

Parkinson's disease (PD) is a complex, progressive neurodegenerative condition affecting more than $1 \%$ of the population over 65 years of age. By the time clinical symptoms appear, around 50\% dopaminergic neurons in the substantia nigra pars compacta (SNpc), are lost. Most PD cases exhibit abnormal intracellular protein aggregates called Lewy bodies. These are composed largely of aggregated a-synuclein (a-syn). With the progression of the disease, the neurodegeneration in this region reaches $90 \%$, while dopaminergic neuron loss in the dorsal tier may be as low as $25 \%$, and many other brain regions are relatively unaffected [1]. The striatal selective neurodegeneration is clinically characterized by debilitating motor and non-motor features which cause

severe disability [2]. About $10 \%$ of PD cases are monogenic forms, associated with highly penetrant gene mutations $[3,4]$. However, the majority of PD cases are sporadic, with a complex etiology caused by an interplay of environmental and associated genetic risk factors. Over the last few years, large scale genome-wide association studies (GWAS) and meta-analyses have identified more than 90 loci of different frequency and penetrance associated with sporadic PD risk. Most of the loci confer a small PD risk individually, but have shown to possess a substantial cumulative risk [5-9].

Animal models have been extensively used for PD research. While parkinsonism is frequently induced by acute toxins, more recently transgenic animal models of familial PD genes have been developed. Although these models have provided a better understanding of in vivo mechanisms of PD pathogenesis, they are often limited by a lack of specific neuronal degeneration and fail to recapitulate the progression of the disease and features of movement disorders [11-13]. Researchers have experienced difficulties in translating promising findings from animal models into successful trials in patients, mainly due to species differences in metabolism and in the sequence, pathogenicity, or number of isoforms expressed of key molecules [14-16]. As an appropriate model is fundamental for research and therapeutic development, the emergence of human pluripotent stem cell (hPSC) technology holds great promise to overcome these limitations and recapitulate essential aspects of the homeostatic and pathological alterations of disease-relevant cells in a human genetic background.

\section{Overview of the current PD models using hPSCs}

hPSCs include blastocyst-derived human embryonic stem cells (ESC) [17] and induced-pluripotent stem cells (iPSC), which are reprogrammed from human somatic cells [18]. hPSCs are an innovative and unique alternative mean to model neuronal disease in vitro, as they have the potential to differentiate into multiple neuronal subtypes, as well as glial cells.

Various informative reviews have summarized PD models generated using patient-derived iPSCs- or, more recently, models created by gene-editing technology [19-24], although most are limited to DN modeling and the cell autonomous mechanism of degeneration. In this review, we will introduce new approaches that have greatly improved hPSC disease modeling, thanks to the development of specific protocols of differentiation, recreation of cellular interactions with co-culture experimental paradigms, and 3D cellular systems.

The self-organizing capability of hPSCs permits the creation of three-dimensional aggregates, known as organoids because of their ability to recapitulate cellcell interactions, cellular diversity, and structures found during organ development $[25,26]$. Brain organoids are especially advantageous for modeling adult-onset diseases, as they allow for the differentiation and maturation of neurons and for long-term cultures, in which disease-associated phenotypes can be promoted through multiple or chronic treatments. Organoids enable the inclusion and complex interaction of different cell types in a spatially organized environment, and the possibility to elucidate the contribution of each cell type to a phenotype [27].

Midbrain organoids have been used to study the pathological mechanisms of PD-related gene mutations and have shown the ability to recapitulate hallmarks of the disease $[28,29]$. These studies focused on relatively early time-points and on DNs, not considering cell populations that emerge at later time-points in organoid differentiation, such as astrocytes or oligodendrocytes. The integration of glia to the midbrain organoids would expand the potential of the model, enabling investigation of PD molecular dysregulation, neuro-glia interactions, and neuroinflammation, overall covering each of the main pathways currently implicated in PD pathology.

Among the cell types interacting with DNs, glia have been shown to be critical to faithfully model the in vitro key features of neurodegeneration pathology [30, 31]. Astrocytes and microglia are the two main types of glia. Their specific functions and cross-talk are actively involved in maintaining brain microenvironments [32, 33]. They strictly control neuronal homeostasis through metabolic support, phagocytic function, removal of apoptotic neuronal cells, and inflammatory response with cytokine production [34,35]. In an environment of protracted stress, such as in neurodegenerative disease, glia divert from their beneficial function to take an active role in disease progression. Proinflammatory cytokines released from activated glia can become neurotoxic, enhance protein aggregation, and facilitate disease spread through transmission of protein aggregates to neurons via exosomes [36-39].

While initial PD research focus concentrated on DN intrinsic neuronal dysfunction, the contribution of glia in the pathology progression and development is now being investigated and recognized as decisive. Recently, astrocyte dysfunction has been directly involved in pathological mechanisms contributing to the degeneration of DNs [40, 41], and impacting neuronal levels of $\alpha$-syn [42]. Co-culture systems of hPSC-derived cells 
have shown that familial PD mutations in LRRK2 and ATP13A2 (PARK9) induce astrocytic functional alterations, which results in a pathogenic crosstalk between astrocytes and neurons. Astrocytes harboring these PD mutations exhibit dysfunctional autophagy-lysosomal pathways, which induced toxic propagations of $\alpha$-syn in DNs and neurodegeneration [42, 43]. Microglia are the main cell type responsible for the inflammatory response in the brain. Increasing evidence associates microgliamediated responses with neurodegeneration in PD. Several loci found to be involved in microglia and innate immunity functions have been correlated to PD heritability [44-47], and elevated levels of pro-inflammatory cytokines and reactive microglia in the vicinity of dopaminergic neurons in the SN have been found in postmortem brain samples [48].

\section{Modeling PD in the engineered nigrostriatal niche}

An increasing number of findings implicate numerous processes in the mechanism leading to neurodegeneration in PD, both in degenerating DNs (cell autonomous) and in other cell types (non-cell autonomous). A multicellular co-culture model appears to be essential to better understand the role of PD genes in the pathophysiology of the disease.

Various region-specific human brain organoids have been developed through distinct protocols of differentiation based on knowledge of brain development during embryology [49]. A recent step forward in disease modeling has been the ability to combine different regionspecific pattered organoids into "assembloids" [50-53]. Assembloids bring another level of complexity to modeling, as cells generate a complex microenvironment which mimics essential in vivo aspects, including interregional interactions of differentially patterned cells, formation of neuronal circuits among neuronal subtypes, long-range axonal connections and cell migration [53, 54]. They provide a system in which it is possible to compare the effects of perturbations on selective susceptibility among regions affected and not affected by disease [55]. Furthermore, non-neuronal cell types like microglia or pericytes can also be engineered into assembloids, enabling the integration of vascular and immune systems in the model $[56,57]$.

We propose to combine existing differentiation technologies to engineer the nigrostriatal niche using two different multi-lineages culture models composed of defined neuronal and glial cell types relevant in PD (Fig. 1). Midbrain and forebrain organoid differentiation generates DNs and forebrain medium spiny neurons (MSNs) respectively. Region-patterned glial cells, such as astrocytes and oligodendrocytes arise after extended culture times [58]. Unlike cells derived from neuroectoderm, microglial cells are not present during brain organoid differentiation $[59,60]$, but can be generated separately and later integrated in the co-culture $[30,51,61]$. The

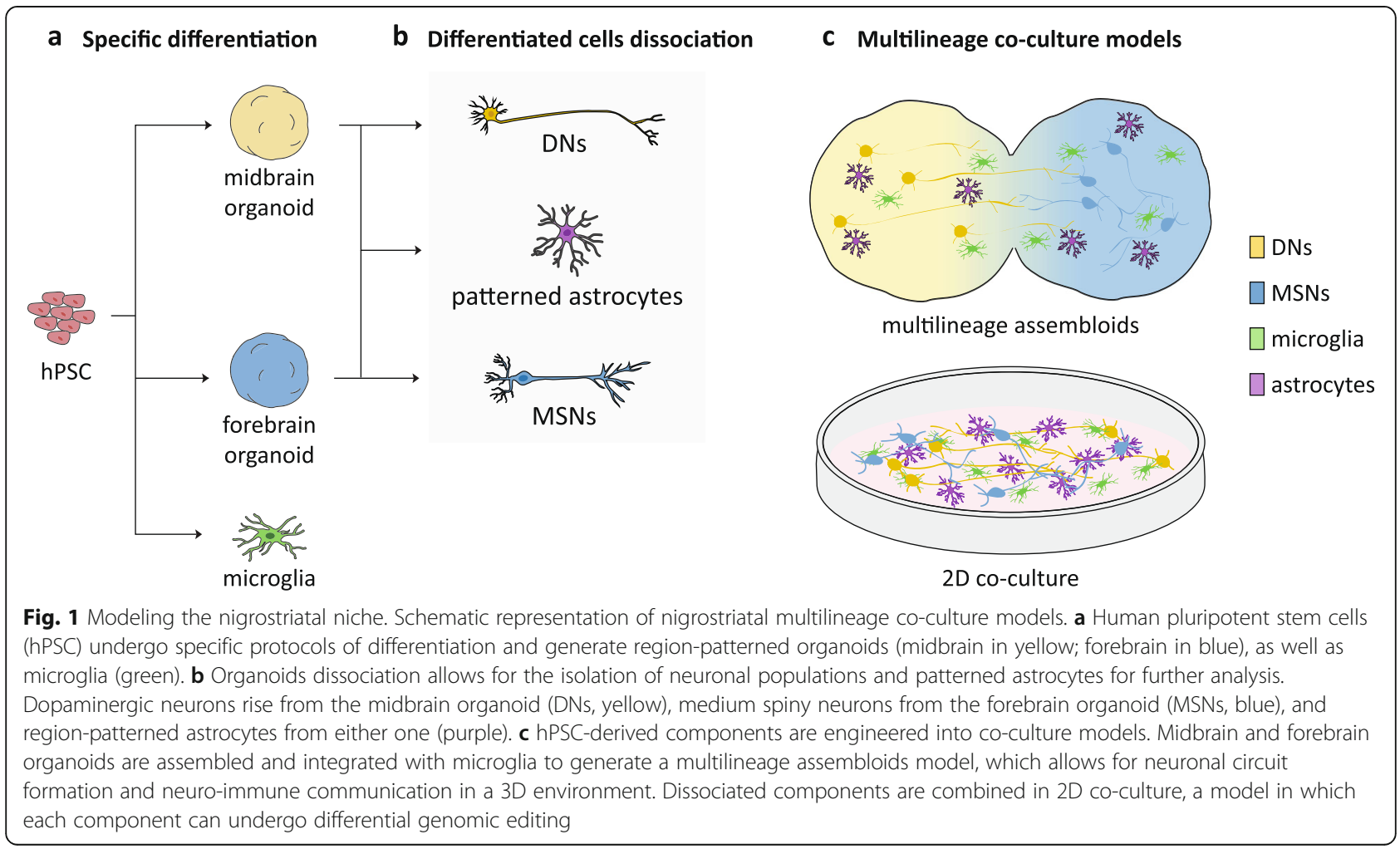


fusion of midbrain and forebrain organoids seeded with microglia would create a complex nigrostriatal cellular environment and a physiologically relevant context to study PD. DNs would be able to establish long-range connections, complex interactions, and rely on glial support to form functional connections to forebrain synaptic targets [62]. Glia may establish neuro-immune communication and improve neuronal maturation [6366].

Patterned brain organoids can be dissociated, and specific cell types can be combined in 2D co-culture. Even though the 2D system loses complexity compared to assembloids, it presents a stable population of cells over time and provides the opportunity to generate fully mixed-genetic models, as distinct cell types can be isolated and mixed from organoids with unique genetic perturbations. Neuro-immune interactions can be dissected among microglia, astrocytes, and neurons in long-term cultures. Both models offer a promising experimental paradigm in which to reproduce the complexity of the disease and explore the role of PD genes in the sequence of aberrant cellular functions at the basis of cell-type-specific neurodegeneration.

\section{Using advanced PD models to understand the role and function of risk genes}

PD genetics are complex and despite recent advances, the majority of identified PD risk variants' contribution to disease pathogenesis is poorly understood. More than 90 PD-related variants have been identified in the most recent GWAS. For most loci, it is still not known which genes underlie PD risk $[8,9,67]$, as each locus identified encompasses hundreds of SNPs, and most lie within non-coding regions of the genome, potentially affecting the regulation of a network of nearby or distant coding genes $[68,69]$.

In order to understand how genetic variation leads to phenotypic differences, current genetic approaches are aimed at (i) identification of additional diseaseassociated SNPs/loci, (ii) fine mapping the causal SNPs and the genes impacted by variants, and (iii) understanding the specific effects of variants on cell types relevant to the pathology, or the combined effects in different cell types.

Several analytic strategies are being used to link specific GWAS loci to the causal genes that influence PD susceptibility [70, 71]. Quantitative trait loci (QTL) mapping correlates variants in genotype and changes in gene expression [72, 73]; the integration of previous genomic and functional annotation, single-cell RNA [74] or transcriptomic data [75] permits the determination of candidates' expression in pathologically relevant cell populations or physiological contexts.
Once high-throughput studies prioritize candidate genetic variants related to the disease, the integration of gene editing tools such as CRISPR can be used to validate causal variants and genes and pinpoint the effect on disease-related phenotypes (Fig. 2). CRISPR genome editing allows for reengineering of the genome, epigenome, and transcriptome of cells [76]. The combination advances in both gene editing and hPSC technologies provide a powerful tool to test cell-type-specific effects of candidate genes and variants in isogenic models (reviewed in [20,77, 78]). The strictly controlled and consistent genomic background enables the identification of even subtle in vitro phenotypes [79-81] and will be useful in efforts to stratify PD on a molecular level and identify a common therapeutic angle. In our lab, we used isogenic models to compare three distinct early-onset autosomal recessive forms of $\mathrm{PD}$ through CRISPR-mediated knockout (KO) of PARKIN, $A T P 13 A 2$, and DJ-1. We observed a significant loss of DNs in PARKIN-KOs and showed dysregulation of the main pathways involved in PD [82] in all PD lines, including common mitochondrial dysfunction as well as lysosomal dysregulation and oxidative stress [29]. Taking these steps further, the recent iPSC Neurodegeneration Disease Initiative (iNDI) project is the largest genome editing project focused on Alzheimer's Disease and related dementias, including a series of PD-causing mutations and as genetic risk factors such as GBA. These lines will be CRISPR edited into hPSC lines from unaffected individuals. iNDI will provide high-quality, deeply characterized isogenic iPSC lines that will be freely shared across the research community. Once available, this resource will greatly extend our ability to test common dysregulations in PD and our understanding of the related pathology [83].

In the past few years, CRISPR-mediated gene editing of PD genes has been successfully applied for many purposes in hPSC-derived models (reviewed in [84]). Phenotypes induced by autosomal dominant PD mutations have been explored by CRISPR-mediated correction and phenotype rescue. For example, the removal of two alleles in SNCA triplication iPSCs showed lower levels of $\alpha$-syn aggregation and stress response [85]. Correction of A53T SNCA mutation has shown $\alpha$-syn aggregation and lysosomal dysfunction associated with the pathogenic form [86]. LRRK2 G2019S point mutation, which is estimated to account for $1 \%$ of sporadic and $4 \%$ of familial PD patients [87], has been explored in several models. Mutation correction both in neurons [88] and astrocytes [43] as well as the introduction of the mutation in midbrain organoids [28], has implicated it in lysosomal dysfunction, $\alpha$-syn accumulation, and neuronal cell death. In 2016, CRISPR was used to elucidate the effect of a common PD genetic risk variant at the 


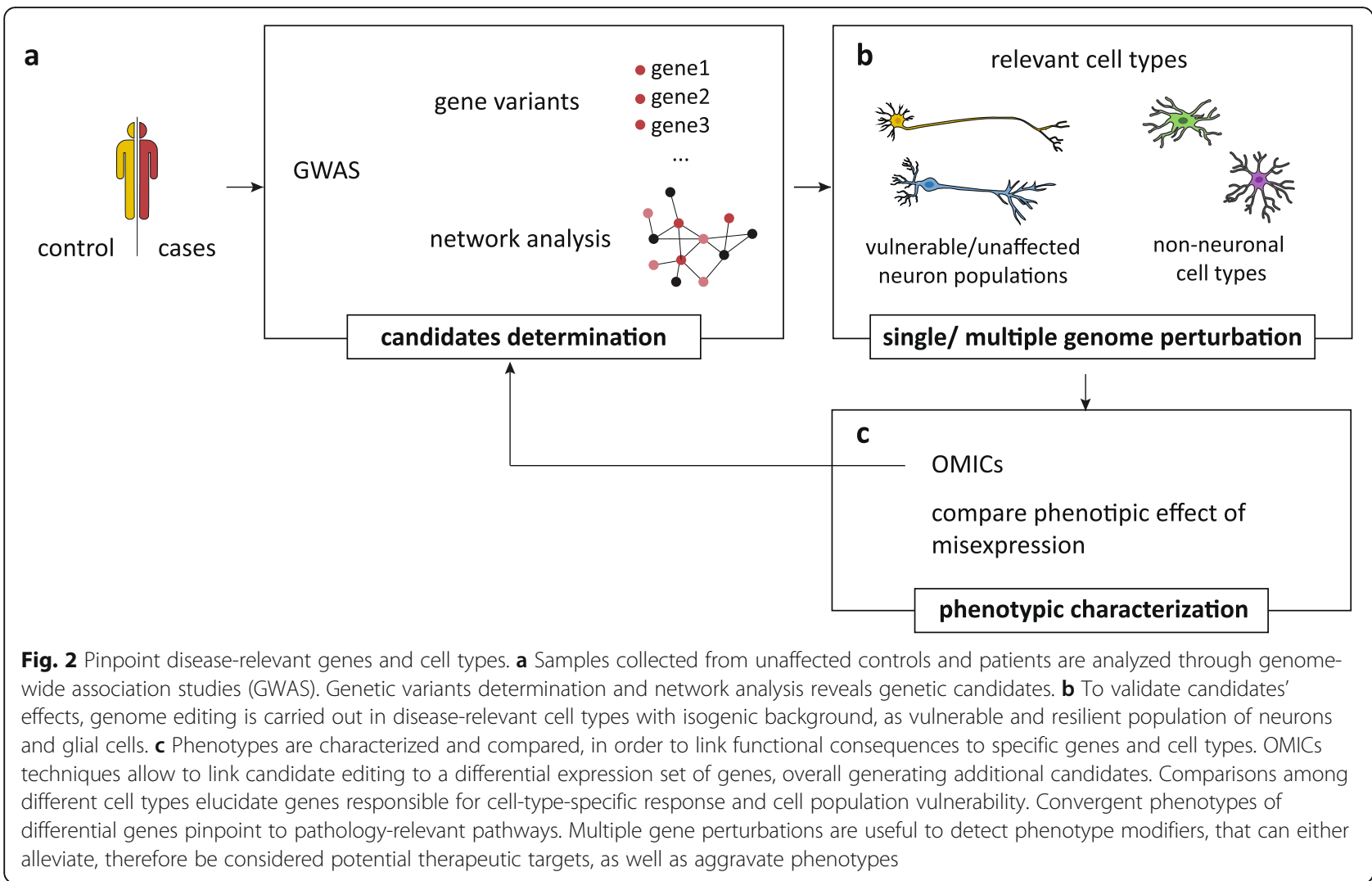

SNCA locus on a molecular level. The risk-associated SNP, found in a non-coding distal enhancer element, was shown to significantly alter the expression of $\alpha$-syn [89].

CRISPR-KO of several PD genes has pointed to the pathogenesis associated with their misexpression. A study using loss of DJ-1 models connected this mutation to commonly dysregulated PD pathways involving elevated $\alpha$-syn, dysregulated $G B A$, as well as mitochondrial and lysosomal dysfunction and showed that oxidized dopamine may be part of the pathology. It was suggested that aspects of the observed pathology were unique in human models and not seen in mouse models which has been attributed to differences in dopamine metabolism [16].

Several technical challenges still remain. It is important to note that hPSCs are prone to genomic instability, abnormalities, or chromosome aberration, especially during long-term cultures or upon transgene transfection [90-92]. Moreover, genome editing may also cause unwanted edits, off-target effects, or transgene silencing upon hPSC differentiation [93]. Genome editing technology is in continuous advancement and the identification and application of new CRISPR effectors is constantly improving editing specificity, efficiency, genome stability, and target accuracy [94, 95].

Recent efforts in the scientific community have generated collaborative and international programs, such as the Global Parkinson's Genetics Program (GP2) that will genotype more than 150,000 volunteers from a different ethnic background, or the Parkinson's Progression Markers Initiative (PPMI) that will collect longitudinal clinical data and biosamples, including iPSCs generated from patients [96]. The availability of a robust and accurate PD model will be essential to maximize these resources to clarify PD genetic architecture and pathogenic pathways. The nigrostriatal niche, built on the conjunction of genome editing and multi-lineage modeling, offers a system in which to consider and compare gene perturbation among vulnerable and nonvulnerable populations of neurons. Each component of the model can undergo a different genetic edit, to recognize cell-specific effects of pathological gene mutations. Moreover, it holds promising advantages for future research to translate GWAS findings into cell-typespecific phenotypes as the identification of new CRISPR systems is increasing the ability to manipulate simultaneously several genes and multiple SNPs $[97,98]$.

Modeling GBA, the major genetic risk factor in PD A clear connection has been established between PD and the alteration of lysosomal pathways [99, 100]. Several familial PD genes as well as identified risk factors for sporadic PD converge in the function of this organelle. Among these, $G B A$ is the most common genetic 
risk factor for PD and provides an ideal target for the nigrostriatal experimental model (Table 2). GBA is expressed in all cell types and encodes the lysosomal enzyme GCase. A decrease in GCase activity results in accumulation of its substrate, glucocerebroside, and compromised activity of the autophagy-lysosomal pathway [116]. The consequences of GBA mutations and GCase loss of function have been strongly linked to several pathological processes and hallmarks of PD in hPSC-derived midbrain DNs. GCase loss of function and lysosomal alteration compromise protein degradation, elevated $\alpha$-syn levels and toxic buildup of aggregates in DNs [111, 117-120]. Glycosylceramide accumulation resulting from reduced GCase has been linked to several pathological pathways: deficit in autophagic flux, calcium imbalance [121], endoplasmic reticulum stress [122], and reduced dopamine storage and uptake [119, 123, 124]. iPSC-derived neurons from GD patients have shown several electrophysiological abnormalities, such as defects in action potential firing. Treatment of control iPSC neurons with a GCase inhibitor results in a similar phenotype, implicating GCase activity in the observed abnormal neuronal electrophysiological properties [125]. GCase activity has been suggested to play a role in PD pathogenesis even in the absence of GBA mutations. Other PD-related mutations, such as deficiency of the late endolysosomal transporter ATP13A2 (PARK9) have been recently shown to alter lysosomal function and decrease GCase activity in both DNs and astrocytes [42]. Additionally, accumulation of $\alpha$-syn aggregates inhibits lysosomal maturation and activity of

Table 2 The complex role of GBA in PD pathology

The GBA gene encodes the lysosomal enzyme glucocerebrosidase (GCase), responsible for the hydrolysis of glucocerebroside to glucose and ceramide [101]. Biallelic mutations in GBA result in GCase deficiency and cause Gaucher disease (GD), an autosomal recessive systemic lysosomal storage disorder with a complex pathogenesis [102, 103]. Heterozygous mutations in GBA, have been found to increase the risk of developing PD by 20-30-fold and are more than 5 times more likely to be found in PD patients compared to controls [104-106]. Clinical observations show that GBA-associated PD may have an earlier onset and higher risk of developing non-motor symptoms such as dementia and depression [107, 108].

Although the role of GBA mutations as risk factors for PD is well established, the mechanism underlying GBA-associated PD is still not clear.

Glucocerebrosidase has a complex biology. The majority of GBA mutation carriers do not develop PD, and there is great variability in symptoms and clinical presentations in both GD and PD patients carrying the same mutations, suggesting the existence of modifying factors such as gene co-variants and environmental factors [109-111]. Decreased GCase activity is also found in patients with PD without GBA mutations, suggesting a central role of the enzyme in the pathogenesis of PD $[112,113]$. Many different GBA mutations have been linked to PD disease including those resulting in null alleles and structural protein alteration that can affect stability or trafficking to the lysosome, as well as changes not related to enzymatic activity $[114,115]$. normal GCase, giving rise to a self-propagating bidirectional pathogenic loop that eventually leads to neurodegeneration [126, 127].

Studies of GBA have mainly focused on dysfunction in isolated cell types, which fails to model the complex interplay between other factors contributing to phenotype. $G B A$ is expressed in all cell types, including glia $[40,128,129]$, and is involved in essential processes for these cells, such as neuroimmune response and phagocytic activity $[130,131]$. The first study considering the role of $G B A$ mutation in glia with a human genetic background clearly suggests that astrocytes with mutant GBA may contribute to PD pathology. Residual levels of GCase activity in iPSC-derived astrocytes generated from GD patients appear to determine the degree of astrogliosis, inflammatory response, and ability to process $\alpha$-syn [132].

Although GBA has been linked to lysosomal functionality in isolated neuronal and glial cells, existing methods fail to resolve the relationship between $G B A$ and PD pathogenesis, as they do not explain cell type vulnerability and incomplete penetrance of $G B A$ variants. The nigrostriatal multilineage assembloid model offers an innovative complex co-culture paradigm that overcomes previous limitations to our understanding of the complexity of gene-variant induced phenotypes. Isogenic hPSC cell lines can be differentiated into glia, susceptible or unaffected neuronal populations, and combined in genetically mixed co-culture to dissect cell-type contributions to pathological phenotypes (Fig. 3). Using high-density SNP arrays different genes have been reported to influence $G B A$-associated risk of disease [133] and could partially explain the observed low penetrance. Emerging CRISPR system tools enable us to simultaneously target multiple genes and evaluate how different variants with individually small effect may synergistically affect $G B A$ pathways and aggravate or ameliorate PD phenotypes [97, 134].

\section{Extending the complex hPSC models to study other neurodegenerative diseases}

Neurological disorders are the leading source of disability globally [135]. A common clinical feature shared among different neurodegenerative diseases is the presence of protein-based deposits as intracellular inclusions and/or as extracellular aggregates, present in specific neuronal types in distinct regions of the brain [136-139] (Table 3). Genetic studies and experimental findings have shown that both genetic and environmental factors impact the onset and progression of the pathology [140, 141].

In most cases, the proteins and genes implicated in the etiology of these diseases have a widespread, ubiquitous expression; nevertheless, the degeneration selectively 


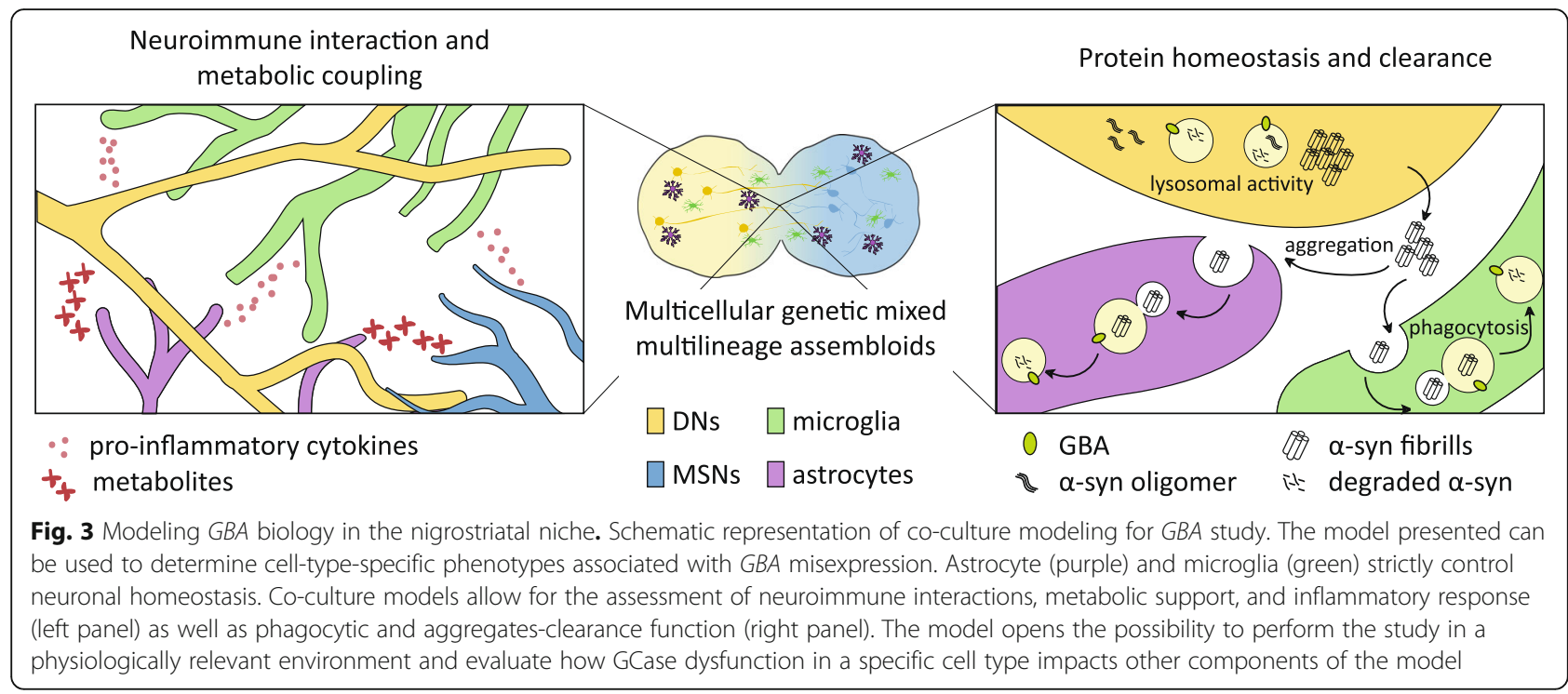

targets specific neuronal types and regions. A major unresolved question in the field is the mechanism underlying the selective vulnerability of specific neuronal subpopulations.

The complexity of neurodegenerative diseases requires new methods to understand the specific dysfunction and multifactorial origins contributing to disease pathogenesis. With the recent development of specific differentiation protocols [142-144], multicellular assembloid models can be extended to study the mechanisms involved in other neurodegenerative diseases in which single gene differences can point to pathological mechanisms in a specific cell type, but mostly do not explain cell type vulnerability. For example, Huntington's disease is characterized by widespread cell death in the striatum of carriers of the mutant huntingtin gene. The most vulnerable and first neurons to degenerate are MSNs of the striatum, while other regions are unaffected [145]. The molecular basis underlying this highly specific neurodegeneration is still not clear. The nigrostriatal model proposed could be used to model huntingtin gene mutation in MSNs and others cell types in order to

Table 3 Neurodegenerative disease unique protein aggregates and neuronal susceptibility

\begin{tabular}{lll}
\hline & Protein inclusion & $\begin{array}{l}\text { Most vulnerable } \\
\text { neuronal population }\end{array}$ \\
\hline $\begin{array}{l}\text { Alzheimer's } \\
\text { disease }\end{array}$ & $\begin{array}{l}\text { Neurofibrillary tangles } \\
\text { (phosphorylated tau); } \\
\text { amyloid plaques (amyloid } \beta \\
\text { peptide) }\end{array}$ & $\begin{array}{l}\text { Pyramidal neurons } \\
\text { (entorhinal cortex, } \\
\text { hippocampus, locus } \\
\text { coeruleus) }\end{array}$ \\
$\begin{array}{l}\text { Parkinson's } \\
\text { disease }\end{array}$ & $\begin{array}{l}\text { Lewy bodies (a-synuclein) } \\
\text { Huntington's } \\
\text { disease }\end{array}$ & $\begin{array}{l}\text { DA neurons (substantia } \\
\text { nigra pars compacta) }\end{array}$ \\
\hline
\end{tabular}

clarify the possible involvement of non-autonomous cell functions.

Multi-lineage assembloids are a scalable system in which to integrate several variables and risk factors related to neurodegenerative diseases simultaneously. The model offers a novel experimental paradigm which takes complexity and phenotypic heterogeneity into consideration [146]. Understanding the basis for cell type vulnerability and the factors involved in disease pathogenesis will provide insights regarding how to specifically intervene to reverse cellular dysfunction, support the affected cell types, and enable the development and testing of future therapeutics.

\section{Abbreviations}

a-syn: a-Synuclein; DNs: Dopaminergic neurons; GCase: Glucocerebrosidase; GD: Gaucher disease; GWAS: Genome-wide association studies;

hESCs: Embryonic stem cells; hPSCs: Human pluripotent stem cells; iPSCs: Induced PSCs; MSNs: Medium spiny neurons; PD: Parkinson's disease; QTL: Quantitative trait loci; SNpc: Substantia nigra pars compacta

\section{Acknowledgements}

The authors thank Dr. Kristen Brennand and Dr. Ellen Sidransky for critical reading and suggestions.

\section{Authors' contributions}

E.C. and T.A. designed the concept of the review and wrote the manuscript. The authors read and approved the final manuscript.

\section{Funding}

This work was supported by funding from NIH 1R01NS114239-01A1, Michael J. Fox Foundation (MJFF) and the Silverstein Foundation.

Availability of data and materials

Not applicable, no data were generated in the study.

\section{Declarations}

Ethics approval and consent to participate Not applicable. 


\section{Consent for publication}

Not applicable.

\section{Competing interests}

The authors declare that they have no competing interests.

\section{Author details}

${ }^{1}$ Nash Family Department of Neuroscience, Icahn School of Medicine at Mount Sinai, New York 10029, NY, US. ²Department of Neurology, Icahn School of Medicine at Mount Sinai, New York 10029, NY, US. ${ }^{3}$ Friedman Brain Institute, Icahn School of Medicine at Mount Sinai, New York 10029, NY, US. ${ }^{4}$ Ronald M. Loeb Center for Alzheimer's Disease, Icahn School of Medicine at Mount Sinai, New York 10029, NY, US. ${ }^{5}$ Black Family Stem Cell Institute, Icahn School of Medicine at Mount Sinai, New York 10029, NY, US.

\section{Received: 3 November 2020 Accepted: 5 April 2021}

\section{Published online: 29 April 2021}

\section{References}

1. Double KL. Neuronal vulnerability in Parkinson's disease. Park Relat Disord. 2012;18 Suppl 1:S52-4.

2. Poewe W, Seppi K, Tanner CM, Halliday GM, Brundin P, Volkmann J, Schrag AE, Lang AE. Parkinson disease. Nat Rev Dis Primers. 2017;3:17013. https:// doi.org/10.1038/nrdp.2017.13.

3. Lill CM. Genetics of Parkinson's disease. Mol Cell Probes. 2016;30(6):386-96 https://doi.org/10.1016/..mcp.2016.11.001.

4. Blauwendraat $C$, Nalls MA, Singleton $A B$. The genetic architecture of Parkinson's disease. Lancet Neurol. 2020;19(2):170-8. https://doi.org/10.1016/ S1474-4422(19)30287-X.

5. Iwaki H, Blauwendraat C, Leonard HL, Liu G, Maple-Grødem J, Corvol JC, et al. Genetic risk of Parkinson disease and progression: an analysis of 13 longitudinal cohorts. Neurol Genet. 2019;5(4):e348.

6. Kim CY, Alcalay RN. Genetic forms of Parkinson's disease. Semin Neurol. 2017;37(02):135-46. https://doi.org/10.1055/s-0037-1601567.

7. Kalinderi K, Bostantjopoulou S, Fidani L. The genetic background of Parkinson's disease: current progress and future prospects. Acta Neurol Scand. 2016;134(5):314-26. https://doi.org/10.1111/ane.12563.

8. Nalls MA, Blauwendraat C, Vallerga CL, Heilbron K, Bandres-Ciga S, Chang D, Tan M, Kia DA, Noyce AJ, Xue A, Bras J, Young E, von Coelln R, SimónSánchez J, Schulte C, Sharma M, Krohn L, Pihlstrøm L, Siitonen A, Iwaki H, Leonard H, Faghri F, Gibbs JR, Hernandez DG, Scholz SW, Botia JA, Martinez M, Corvol JC, Lesage S, Jankovic J, Shulman LM, Sutherland M, Tienari P, Majamaa K, Toft M, Andreassen OA, Bangale T, Brice A, Yang J, Gan-Or Z, Gasser T, Heutink P, Shulman JM, Wood NW, Hinds DA, Hardy JA, Morris HR, Gratten J, Visscher PM, Graham RR, Singleton AB, Adarmes-Gómez AD, Aguilar M, Aitkulova A, Akhmetzhanov V, Alcalay RN, Alvarez I, Alvarez V, Bandres-Ciga S, Barrero FJ, Bergareche Yarza JA, Bernal-Bernal I, Billingsley K, Blauwendraat C, Blazquez M, Bonilla-Toribio M, Botía JA, Boungiorno MT, Bras J, Brice A, Brockmann K, Bubb V, Buiza-Rueda D, Cámara A, Carrillo F, Carrión-Claro M, Cerdan D, Chelban V, Clarimón J, Clarke C, Compta Y, Cookson MR, Corvol JC, Craig DW, Danjou F, Diez-Fairen M, Dols-Icardo O, Duarte J, Duran R, Escamilla-Sevilla F, Escott-Price V, Ezquerra M, Faghri F, Feliz C, Fernández M, Fernández-Santiago R, Finkbeiner S, Foltynie T, Gan-Or Z, Garcia C, García-Ruiz P, Gasser T, Gibbs JR, Gomez Heredia MJ, GómezGarre P, González MM, Gonzalez-Aramburu I, Guelfi S, Guerreiro R, Hardy J, Hassin-Baer S, Hernandez DG, Heutink P, Hoenicka J, Holmans P, Houlden H, Infante J, Iwaki H, Jesús S, Jimenez-Escrig A, Kaishybayeva G, Kaiyrzhanov R, Karimova A, Kia DA, Kinghorn KJ, Koks S, Krohn L, Kulisevsky J, LabradorEspinosa MA, Leonard HL, Lesage S, Lewis P, Lopez-Sendon JL, Lovering R, Lubbe S, Lungu C, Macias D, Majamaa K, Manzoni C, Marín J, Marinus J, Marti MJ, Martinez M, Martínez Torres I, Martínez-Castrillo JC, Mata M, Mencacci NE, Méndez-del-Barrio C, Middlehurst B, Mínguez A, Mir P, Mok KY, Morris HR, Muñoz E, Nalls MA, Narendra D, Noyce AJ, Ojo OO, Okubadejo NU, Pagola AG, Pastor P, Perez Errazquin F, Periñán-Tocino T, Pihlstrom L, Plun-Favreau H, Quinn J, R'Bibo L, Reed X, Rezola EM, Rizig M, Rizzu P, Robak L, Rodriguez AS, Rouleau GA, Ruiz-Martínez J, Ruz C, Ryten M, Sadykova D, Scholz SW, Schreglmann S, Schulte C, Sharma M, Shashkin C, Shulman JM, Sierra M, Siitonen A, Simón-Sánchez J, Singleton AB, SuarezSanmartin E, Taba P, Tabernero C, Tan MX, Tartari JP, Tejera-Parrado C, Toft M, Tolosa E, Trabzuni D, Valldeoriola F, van Hilten JJ, van Keuren-Jensen K, Vargas-González L, Vela L, Vives F, Williams N, Wood NW, Zharkinbekova N,
Zharmukhanov Z, Zholdybayeva E, Zimprich A, Ylikotila P, Shulman LM, von Coelln R, Reich S, Savitt J, Agee M, Alipanahi B, Auton A, Bell RK, Bryc K, Elson SL, Fontanillas P, Furlotte NA, Huber KE, Hicks B, Jewett EM, Jiang Y, Kleinman A, Lin KH, Litterman NK, McCreight JC, McIntyre MH, McManus KF, Mountain JL, Noblin ES, Northover CAM, Pitts SJ, Poznik GD, Sathirapongsasuti JF, Shelton JF, Shringarpure S, Tian C, Tung J, Vacic V, Wang X, Wilson CH, Anderson T, Bentley S, Dalrymple-Alford J, Fowdar J, Gratten J, Halliday G, Henders AK, Hickie I, Kassam I, Kennedy M, Kwok J, Lewis S, Mellick G, Montgomery G, Pearson J, Pitcher T, Sidorenko J, Silburn PA, Vallerga CL, Visscher PM, Wallace L, Wray NR, Xue A, Yang J, Zhang F. Identification of novel risk loci, causal insights, and heritable risk for Parkinson's disease: a meta-analysis of genome-wide association studies. Lancet Neurol. 2019;18(12):1091-102. https://doi.org/10.1016/S1474-4422 (19)30320-5.

9. Blauwendraat $C$, Heilbron $K$, Vallerga $C L$, Bandres-Ciga S, von Coelln R, Pihlstrøm L, Simón-Sánchez J, Schulte C, Sharma M, Krohn L, Siitonen A, Iwaki H, Leonard H, Noyce AJ, Tan M, Gibbs JR, Hernandez DG, Scholz SW, Jankovic J, Shulman LM, Lesage S, Corvol JC, Brice A, van Hilten JJ, Marinus $J$, The 23andMe Research Team, Eerola-Rautio J, Tienari P, Majamaa K, Toft M, Grosset DG, Gasser T, Heutink P, Shulman JM, Wood N, Hardy J, Morris HR, Hinds DA, Gratten J, Visscher PM, Gan-Or Z, Nalls MA, Singleton AB, for the International Parkinson's Disease Genomics Consortium (IPDGC) Parkinson's disease age at onset genome-wide association study: defining heritability, genetic loci, and a-synuclein mechanisms. Mov Disord. 2019; 34(6):866-75. https://doi.org/10.1002/mds.27659.

10. Hartmann A. Postmortem studies in Parkinson's disease. Dialogues Clin Neurosci. 2004;6(3):281-93.

11. Kin K, Yasuhara T, Kameda M, Date I. Animal models for Parkinson's disease research: trends in the 2000s. Int J Mol Sci. 2019;20(21). https://doi.org/10.33 90/ijms20215402.

12. Zeng XS, Geng WS, Jia JJ. Neurotoxin-induced animal models of Parkinson disease: pathogenic mechanism and assessment. ASN Neuro. 2018;10: 1759091418777438

13. Creed RB, Goldberg MS. New Developments in Genetic rat models of Parkinson's Disease. Mov Disord. 2018. p. 717-29. Available from: https:// pubmed.ncbi.nlm.nih.gov/29418019/. [cited 2020 Aug 19].

14. Sasaguri H, Nilsson P, Hashimoto S, Nagata K, Saito T, De Strooper B, et al. APP mouse models for Alzheimer's disease preclinical studies. EMBO J. 2017; 36:e201797397 Available from: http://emboj.embopress.org/lookup/doi/10.1 5252/embj.201797397.

15. Li H, Jiang H, Zhang B, Feng J. Modeling Parkinson's disease using patientspecific induced pluripotent stem cells. J Parkinsons Dis. 2018;8(4):479-93. https://doi.org/10.3233/JPD-181353.

16. Burbulla LF, Song P, Mazzulli JR, Zampese E, Wong YC, Jeon S, et al. Dopamine oxidation mediates mitochondrial and lysosomal dysfunction in Parkinson's disease. Science. 2017;357(6357):1255-61.

17. Thomson JA. Embryonic stem cell lines derived from human blastocysts. Science. 1998;282(5391):1145-7.

18. Takahashi K, Tanabe K, Ohnuki M, Narita M, Ichisaka T, Tomoda K, Yamanaka S. Induction of pluripotent stem cells from adult human fibroblasts by defined factors. Cell. 2007:131(5):861-72

19. Zhang Q, Chen W, Tan S, Lin T. Stem cells for modeling and therapy of Parkinson's disease. Hum Gene Ther. 2017. p. 85-98. Available from: https:// pubmed.ncbi.nlm.nih.gov/27762639/. [cited 2020 Aug 19].

20. Hu X, Mao C, Fan L, Luo H, Hu Z, Zhang S, Yang Z, Zheng H, Sun H, Fan Y, Yang J, Shi C, Xu Y. Modeling Parkinson's disease using induced pluripotent stem cells. Stem Cells Int. 2020;2020:1-15. https://doi.org/10.1155/2020/1 061470

21. Safari F, Hatam G, Behbahani AB, Rezaei V, Barekati-Mowahed M, Petramfar $P$, et al. CRISPR system: a high-throughput toolbox for research and treatment of Parkinson's disease Cell Mol Neurobiol. 2020. p. 477-93. Available from: https://pubmed.ncbi.nlm.nih.gov/31773362/. [cited 2020 Aug 19].

22. Sison SL, Vermilyea SC, Emborg ME, Ebert AD. Using patient-derived induced pluripotent stem cells to identify Parkinson's disease-relevant phenotypes. Curr Neurol Neurosci Rep. 2018. Available from: https:// pubmed.ncbi.nlm.nih.gov/30284665/. [cited 2020 Aug 19].

23. Ke M, Chong CM, Su H. Using induced pluripotent stem cells for modeling Parkinson's disease. World J Stem Cells. 2019;11(9):634-49.

24. Avazzadeh S, Baena JM, Keighron C, Feller-Sanchez Y, Quinlan LR. Modelling Parkinson's disease: iPSCs towards better understanding of human 
pathology. Brain Sci. 2021;11:373 Available from: https://www.mdpi.com/2 076-3425/11/3/373. [cited 2021 Mar 22].

25. Lancaster MA, Knoblich JA. Organogenesisin a dish: modeling development and disease using organoid technologies. Science. 2014;345(6194):1247125.

26. McCauley HA, Wells JM. Pluripotent stem cell-derived organoids: using principles of developmental biology to grow human tissues in a dish. Dev. 2017;144(6):958-62. https://doi.org/10.1242/dev.140731.

27. Tambalo M. Brain organoids: human 3D models to investigate neuronal circuits assembly, function and dysfunction; 2020;1746:147028.

28. Kim H, Park HJ, Choi H, Chang Y, Park H, Shin J, Kim J, Lengner CJ, Lee YK, Kim J. Modeling G2019S-LRRK2 sporadic Parkinson's disease in 3D midbrain organoids. Stem Cell Rep. 2019;12(3):518-31. https://doi.org/10.1016/j. stemcr.2019.01.020,

29. Ahfeldt T, Ordureau A, Bell C, Sarrafha L, Sun C, Piccinotti S, et al. Pathogenic pathways in early-onset autosomal recessive Parkinson's disease discovered using isogenic human dopaminergic neurons. Stem Cell Rep. 2020;14(1):75-90. Available from: http://www.ncbi.nlm.nih.gov/pubmed/31902706.

30. Park J, Wetzel I, Marriott I, Dréau D, D'Avanzo C, Kim DY, Tanzi RE, Cho H. A 3D human triculture system modeling neurodegeneration and neuroinflammation in Alzheimer's disease. Nat Neurosci. 2018;21(7):941-51. https://doi.org/10.1038/s41593-018-0175-4

31. Chang CY, Ting HC, Liu CA, Su HL, Chiou TW, Lin SZ, et al. Induced pluripotent stem cell (iPSC)-based neurodegenerative disease models for phenotype recapitulation and drug screening. Molecules. 2020;25:1-21.

32. Yun SP, Kam TI, Panicker N, Kim S, Oh Y, Park JS, Kwon SH, Park YJ, Karuppagounder SS, Park H, Kim S, Oh N, Kim NA, Lee S, Brahmachari S, Mao X, Lee JH, Kumar M, An D, Kang SU, Lee Y, Lee KC, Na DH, Kim D, Lee SH, Roschke W, Liddelow SA, Mari Z, Barres BA, Dawson VL, Lee S, Dawson $\mathrm{TM}$, Ko HS. Block of A1 astrocyte conversion by microglia is neuroprotective in models of Parkinson's disease. Nat Med. 2018;24(7):931-8. https://doi. org/10.1038/s41591-018-0051-5.

33. Jha MK, Jo M, Kim JH, Suk K. Microglia-astrocyte crosstalk: an intimate molecular conversation. Neuroscientist. 2019;25(3):227-40.

34. Vezzani A, Viviani B. Neuromodulatory properties of inflammatory cytokines and their impact on neuronal excitability. Neuropharmacology. 2015;96(Pt A):70-82.

35. Timmerman R, Burm SM, Bajramovic JJ. An overview of in vitro methods to study microglia. Front Cell Neurosci. 2018;12:242.

36. Duffy MF, Collier TJ, Patterson JR, Kemp CJ, Luk KC, Tansey MG, et al. Correction: Lewy body-like alpha-synuclein inclusions trigger reactive microgliosis prior to nigral degeneration J Neuroinflammation. 2018:15 (129) doi: https://doi.org/10.1186/s12974-018-1171-z.

37. Fellner L, Irschick R, Schanda K, Reindl M, Klimaschewski L, Poewe W, Wenning GK, Stefanova N. Toll-like receptor 4 is required for a-synuclein dependent activation of microglia and astroglia. Glia. 2013;61(3):349-60. https://doi.org/10.1002/glia.22437.

38. Doorn KJ, Moors T, Drukarch B, van de Berg WDJ, Lucassen PJ, van Dam AM. Microglial phenotypes and toll-like receptor 2 in the substantia nigra and hippocampus of incidental Lewy body disease cases and Parkinson's disease patients. Acta Neuropathol Commun. 2014;2:90.

39. Guo M, Wang J, Zhao Y, Feng Y, Han S, Dong Q, Cui M, Tieu K. Microglial exosomes facilitate a -synuclein transmission in Parkinson's disease. 2020; 143(5):1476-97.

40. Booth HDE, Hirst WD, Wade-Martins R. The role of astrocyte dysfunction in Parkinson's disease pathogenesis. Trends Neurosci. 2017;40(6):358-70.

41. Miyazaki I, Asanuma M. Neuron-astrocyte interactions in Parkinson's disease. Cells. NLM (Medline); 2020. p. 2623. Available from: www.mdpi.com/journal/ cells. [cited 2021 Feb 12].

42. Tsunemi T, Ishiguro Y, Yoroisaka A, Valdez C, Miyamoto K, Ishikawa K, et al. Astrocytes protect human dopaminergic neurons from a-synuclein accumulation and propagation. J Neurosci 2020;40(45):8618-28. Available from: http://www.ncbi.nlm.nih.gov/pubmed/33046546.

43. di Domenico A, Carola G, Calatayud C, Pons-Espinal M, Muñoz JP, RichaudPatin Y, Fernandez-Carasa I, Gut M, Faella A, Parameswaran J, Soriano J, Ferrer I, Tolosa E, Zorzano A, Cuervo AM, Raya A, Consiglio A. Patientspecific iPSC-derived astrocytes contribute to non-cell-autonomous neurodegeneration in Parkinson's disease. Stem Cell Rep. 2019;12(2):213-29. https://doi.org/10.1016/j.stemcr.2018.12.011.

44. Rayaprolu S, Mullen B, Baker M, Lynch T, Finger E, Seeley WW, et al. TREM2 in neurodegeneration: evidence for association of the p.R47H variant with frontotemporal dementia and Parkinson's disease. Mol Neurodegener. 2013:
8-19 Available from: https://molecularneurodegeneration.biomedcentral. com/articles/10.1186/1750-1326-8-19. [cited 2020 Oct 19].

45. Surendranathan A, Rowe JB, O'Brien JT. Neuroinflammation in Lewy body dementia. Park Relat Disord. 2015;21(12):1398-406.

46. Reynolds RH, Botía J, Nalls MA, Hardy J, Gagliano Taliun SA, Ryten M. Moving beyond neurons: the role of cell type-specific gene regulation in Parkinson's disease heritability. NPJ Park Dis. 2019;5:6.

47. Bartels T, De Schepper S, Hong S. Microglia modulate neurodegeneration in Alzheimer's and Parkinson's diseases. Science. 2020;370(6512):66-9. Available from: http://www.ncbi.nlm.nih.gov/pubmed/33004513.

48. Whitton PS. Inflammation as a causative factor in the aetiology of Parkinson's disease. Br J Pharmacol. 2007;150(8):963-76. https://doi.org/10.1 038/sj.bjp.0707167.

49. Sidhaye J. Brain organoids : an ensemble of bioassays to investigate human neurodevelopment and disease. Cell Death Differ. 2020. https://doi.org/10.1 038/s41418-020-0566-4.

50. Bagley JA, Reumann D, Bian S, Lévi-Strauss J, Knoblich JA. Fused cerebral organoids model interactions between brain regions. Nat Methods. 2017; 14(7):743-51.

51. Pasca SP. Assembling human brain organoids. Science. 2019;363:126-7.

52. Marton RM, Pasca SP. Organoid and assembloid technologies for investigating cellular crosstalk in human brain development and disease. Trends Cell Biol. 2020;30(2):133-43. https://doi.org/10.1016/j.tcb.2 019.11.004.

53. Pasca SP. The rise of three-dimensional human brain cultures Nature.2018. p. 437-45. Available from: https://pubmed.ncbi.nIm.nih.gov/29364288/. [cited 2020 Oct 19].

54. Lancaster MA, Renner M, Martin CA, Wenzel D, Bicknell LS, Hurles ME, et al. Cerebral organoids model human brain development and microcephaly. Nature. 2013;501:373-9 Available from: https://pubmed.ncbi.nlm.nih.gov/23 995685/. [cited 2020 Oct 19].

55. Xiang Y, Cakir B, Park IH. Deconstructing and reconstructing the human brain with regionally specified brain organoids. Semin Cell Dev Biol. 2020; 111:40-51.

56. Blanchard JW, Bula M, Davila-Velderrain J, Akay LA, Zhu L, Frank A, Victor MB, Bonner JM, Mathys H, Lin YT, Ko T, Bennett DA, Cam HP, Kellis M, Tsai $\mathrm{LH}$. Reconstruction of the human blood-brain barrier in vitro reveals a pathogenic mechanism of APOE4 in pericytes. Nat Med. 2020;26(6):952-63. https://doi.org/10.1038/s41591-020-0886-4.

57. Cakir B, Xiang Y, Tanaka Y, Kural MH, Parent M, Kang YJ, et al. Engineering of human brain organoids with a functional vascular-like system. Nat Methods. 2019;16(11):1169-75

58. Velasco S, Kedaigle AJ, Simmons SK, Nash A, Rocha M, Quadrato G, et al. Individual brain organoids reproducibly form cell diversity of the human cerebral cortex. Nature. 2019;570:523-7 Available from: https://www.nature. com/articles/s41586-019-1289-x. [cited 2020 Oct 27].

59. Nayak D, Roth TL, McGavern DB. Microglia development and function. Annu Rev Immunol. 2014;32(1):367-402. https://doi.org/10.1146/annurevimmunol-032713-120240.

60. Di Lullo E, Kriegstein AR. The use of brain organoids to investigate neural development and disease. Nat Rev Neurosci. 2017;18(10):573-84.

61. Song L, Yuan X, Jones Z, Vied C, Miao Y, Marzano M, et al. Functionalization of brain region-specific spheroids with isogenic microglia-like cells. Sci Rep. 2019;9:1-18. https://doi.org/10.1038/s41598019-47444-6 [cited 2020 Aug 4].

62. Hegarty S V., Sullivan AM, O'Keeffe GW. Midbrain dopaminergic neurons: a review of the molecular circuitry that regulates their development. Dev Biol 2013. p. 123-38. Available from: https://pubmed.ncbi.nlm.nih.gov/236031 97/. [cited 2020 Aug 19].

63. Blondel O, Collin C, McCarran WJ, Zhu S, Zamostiano R, Gozes I, et al. A gliaderived signal regulating neuronal differentiation. J Neurosci. 2000;20(21): 8012-20.

64. Stogsdill JA, Eroglu C. The interplay between neurons and glia in synapse development and plasticity. Curr Opin Neurobiol. 2017;42:1-8. https://doi. org/10.1016/j.conb.2016.09.016.

65. Tang X, Zhou L, Wagner AM, Marchetto MCN, Muotri AR, Gage FH, et al. Astroglial cells regulate the developmental timeline of human neurons differentiated from induced pluripotent stem cells. Stem Cell Res. 2013;11(2): $743-57$.

66. Johnson MA, Weick JP, Pearce RA, Zhang SC. Functional neural development from human embryonic stem cells: accelerated synaptic 
activity via astrocyte coculture. J Neurosci. 2007;27(12):3069-77. https://doi. org/10.1523/JNEUROSCI.4562-06.2007.

67. Foo JN, Chew EGY, Chung SJ, Peng R, Blauwendraat C, Nalls MA, et al. Identification of risk loci for Parkinson disease in Asians and comparison of risk between Asians and Europeans: a genome-wide association study. JAMA Neurol 2020; Available from: https://pubmed.ncbi.nlm.nih.gov/323102 70/. [cited 2020 Sep 2].

68. Maurano MT, Humbert R, Rynes E, Thurman RE, Haugen E, Wang H, et al. Systematic localization of common disease-associated variation in regulatory DNA. Science. 2012;337:1190-5 Available from: https://science. sciencemag.org/content/337/6099/1190. [cited 2020 Sep 1].

69. Ohnmacht J, May P, Sinkkonen L, Krüger R. Missing heritability in Parkinson's disease: the emerging role of non-coding genetic variation J Neural Transm 2020. p. 729-48. Available from: /pmc/articles/PMC7242266/?report= abstract. [cited 2020 Sep 1].

70. Grenn F, Kim J, Makarious M, Iwaki H, Illarionova A, Brolin K, et al. The Parkinson's disease GWAS locus browser. bioRxiv 2020;2020.04.01.020404. Available from: doi: https://doi.org/10.1101/2020.04.01.020404. [cited 2020 Aug 19].

71. Cano-Gamez E, Trynka G. From GWAS to function: using functional genomics to identify the mechanisms underlying complex diseases. Front Genet. 2020;11:1-21.

72. Watanabe K, Taskesen E, Van Bochoven A, Posthuma D. Functional mapping and annotation of genetic associations with FUMA. Nat Commun. 2017;8:1-11.

73. Ramdhani S, Navarro E, Udine E, Efthymiou AG, Schilder BM, Parks M, Goate A, Raj T. Tensor decomposition of stimulated monocyte and macrophage gene expression profiles identifies neurodegenerative disease-specific transeQTLs. PLoS Genet. 2020;16(2):e1008549. https://doi.org/10.1371/journal. pgen.1008549, [cited 2020 Sep 1.

74. Hook PW, McClymont SA, Cannon GH, Law WD, Morton AJ, Goff LA, et al. Single-cell RNA-Seq of mouse dopaminergic neurons informs candidate gene selection for sporadic Parkinson disease. Am J Hum Genet. 2018;102: 427-46 Available from: https://pubmed.ncbi.nlm.nih.gov/29499164/. [cited 2020 Sep 2].

75. Li Yl, Wong G, Humphrey J, Raj T. Prioritizing Parkinson's disease genes using population-scale transcriptomic data. Nat Commun. 2019;10(1):994.

76. Adli M. The CRISPR tool kit for genome editing and beyond. Nat Commun. 2018;9(1):1911. https://doi.org/10.1038/s41467-018-04252-2.

77. Kampmann M. CRISPR-based functional genomics for neurological disease. Nat Rev Neurol. 2020;16(9):465-80. https://doi.org/10.1038/s41582-020-0373-z.

78. Doudna JA. The promise and challenge of therapeutic genome editing Nature 2020 p. 229-236. doi: https://doi.org/10.1038/s41586-020-1978-5, 2020. [cited 2021 mar 26].

79. Grobarczyk B, Franco B, Hanon K, Malgrange B. Generation of isogenic human iPS cell line precisely corrected by genome editing using the CRIS PR/Cas9 system. Stem Cell Rev Rep. 2015;11(5):774-87.

80. Xu X, Tay Y, Sim B, Yoon SI, Huang Y, Ooi J, et al. Reversal of phenotypic abnormalities by CRISPR/Cas9-mediated gene correction in Huntington disease patient-derived induced pluripotent stem cells. Stem Cell Rep. 2017; 8:619-33 Available from: https://pubmed.ncbi.nlm.nih.gov/28238795/. [cited 2020 Aug 4].

81. Bhinge A, Namboori SC, Zhang X, VanDongen AMJ, Stanton LW. Genetic correction of SOD1 mutant iPSCS reveals ERK and JNK activated AP1 as a driver of neurodegeneration in amyotrophic lateral sclerosis. Stem Cell Rep. 8:856-69 Available from: https://pubmed.ncbi.nlm.nih.gov/28366453/. [cited 2020 Aug 4].

82. Poewe W, Seppi K, Tanner CM, Halliday GM, Brundin P, Volkmann J, et al. Parkinson disease. Nat Rev Dis Prim. 2017;3:1-21 Available from: https:// pubmed.ncbi.nlm.nih.gov/28332488/. [cited 2020 Oct 23].

83. Ramos DM, Skarnes WC, Singleton AB, Cookson MR, Ward ME. Tackling neurodegenerative diseases with genomic engineering : a new stem cell initiative from the NIH. Neuron. 2021;109(7):1080-3. https://doi.org/10.1016/j. neuron.2021.03.022.

84. Safari F, Hatam G, Behbahani AB, Rezaei V, Barekati-Mowahed M, Petramfar $P$, et al. CRISPR system: a high-throughput toolbox for research and treatment of Parkinson's disease. Cell Mol Neurobiol. 2020:477-93 Available from: https://pubmed.ncbi.nlm.nih.gov/31773362/. [cited 2020 Sep 1].

85. Ludtmann MHR, Angelova PR, Horrocks MH, Choi ML, Rodrigues M, Baev AY, et al. a-Synuclein oligomers interact with ATP synthase and open the permeability transition pore in Parkinson's disease. Nat Commun 2018;9. Available from: https://pubmed.ncbi.nlm.nih.gov/2 9895861/. [cited 2021 Mar 19].
86. Cuddy LK, Wani WY, Morella ML, Pitcairn C, Tsutsumi K, Fredriksen K, et al. Stress-induced cellular clearance is mediated by the SNARE protein ykt6 and disrupted by a-synuclein. Neuron. 2019:104:869-884.e11 Available from: /pmc/articles/PMC6895429/. [cited 2021 Mar 21].

87. Healy DG, Falchi M, O'Sullivan SS, Bonifati V, Durr A, Bressman S, et al. Phenotype, genotype, and worldwide genetic penetrance of LRRK2associated Parkinson's disease: a case-control study. Lancet Neurol. 2008;7: 583-90 Available from: https://pubmed.ncbi.nlm.nih.gov/18539534/. [cited 2021 Mar 19].

88. Qing X, Walter J, Jarazo J, Arias-Fuenzalida J, Hillje AL, Schwamborn JC. CRIS PR/Cas9 and piggyBac-mediated footprint-free LRRK2-G2019S knock-in reveals neuronal complexity phenotypes and a-Synuclein modulation in dopaminergic neurons. Stem Cell Res. 2017;24:44-50. https://doi.org/10.101 6/j.scr.2017.08.013.

89. Soldner F, Stelzer Y, Shivalila CS, Abraham BJ, Latourelle JC, Barrasa MI, et al. Parkinson-associated risk variant in distal enhancer of a-synuclein modulates target gene expression. Nature. 2016;533:95-9 Available from: https:// pubmed.ncbi.nlm.nih.gov/27096366/. [cited 2020 Aug 30].

90. Hussein SM, Batada NN, Vuoristo S, Ching RW, Autio R, E Närvä, et al. Copy number variation and selection during reprogramming to pluripotency. Nature. 2011;471:58-62. Available from: https://www.nature.com/articles/na ture09871. [cited 2021 Feb 11].

91. Dekel-Naftali M, Aviram-Goldring A, Litmanovitch T, Shamash J, ReznikWolf $\mathrm{H}$, Laevsky I, et al. Screening of human pluripotent stem cells using $\mathrm{CGH}$ and FISH reveals low-grade mosaic aneuploidy and a recurrent amplification of chromosome 1q. Eur J Hum Genet. 2012;20: 1248-55 Available from: https://pubmed.ncbi.nlm.nih.gov/22713809/. [cited 2021 Feb 11].

92. Sanders LH, Laganière J, Cooper O, Mak SK, Vu BJ, Huang YA, et al. LRRK2 mutations cause mitochondrial DNA damage in iPSC-derived neural cells from Parkinson's disease patients: reversal by gene correction. Neurobiol Dis. 2014;62:381-6 Available from: https://pubmed.ncbi.nlm.nih.gov/2414 8854/. [cited 2021 Feb 11].

93. Zhang Z, Zhang Y, Gao F, Han S, Cheah KS, Tse HF, et al. CRISPR/Cas9 genome-editing system in human stem cells: current status and future prospects. Mol Ther Nucleic Acids. 2017:230-41 Available from: https:// pubmed.ncbi.nlm.nih.gov/29246302/. [cited 2021 Feb 1].

94. Liu JJ, Orlova N, Oakes BL, Ma E, Spinner HB, Baney KLM, et al. CasX enzymes comprise a distinct family of RNA-guided genome editors. Nature. 2019;566(7743):218-223.

95. Konermann S, Lotfy P, Brideau NJ, Oki J, Shokhirev MN, Hsu PD. Transcriptome engineering with RNA-targeting type VI-D CRISPR effectors. Cell. 2018;173:665-676.e14.

96. Riley EA, Schekman R. Point of view open science takes on Parkinson's disease. Elife. 2021;10:1-6. https://doi.org/10.7554/eLife.66546 [cited 2021 MAR 25].

97. Fernando MB, Ahfeldt T, Brennand KJ. Modeling the complex genetic architectures of brain disease. Nat Genet. 2020;52(4):363-9. Available from: http://www.nature.com/articles/s41588-020-0596-3.

98. Zetsche B, Heidenreich M, Mohanraju P, Fedorova I, Kneppers J, Degennaro EM, et al. Multiplex gene editing by CRISPR-Cpf1 using a single crRNA array. Nat Biotechnol. 2017:35(1):31-4. https://doi.org/10.1038/nbt.3737.

99. Chang D, Nalls MA, Hallgrímsdóttir IB, Hunkapiller J, van der Brug M, Cai F, et al. A meta-analysis of genome-wide association studies identifies 17 new Parkinson's disease risk loci. Nat Genet. 2017;49(10):1511-6. https://doi.org/1 0.1038/ng.3955.

100. Klein AD, Mazzulli JR. Is Parkinson's disease a lysosomal disorder? Brain; 2018.

101. Beutler E. Gaucher disease: New molecular approaches to diagnosis and treatment. Science. 1992;256(5058):794-9.

102. Grabowski GA. Phenotype, diagnosis, and treatment of Gaucher's disease. Lancet. 2008;372(9645):1263-71. https://doi.org/10.1016/S0140-6736(08)61 522-6.

103. Grabowski GA. Gaucher disease and other storage disorders. Hematology Am Soc Hematol Educ Program. 2012;2012:13-8.

104. Sidransky E, Nalls MA, Aasly JO, Aharon-Peretz J, Annesi G, Barbosa ER, BarShira A, Berg D, Bras J, Brice A, Chen CM, Clark LN, Condroyer C, De Marco EV, Dürr A, Eblan MJ, Fahn S, Farrer MJ, Fung HC, Gan-Or Z, Gasser T, Gershoni-Baruch R, Giladi N, Griffith A, Gurevich T, Januario C, Kropp P, Lang AE, Lee-Chen GJ, Lesage S, Marder K, Mata IF, Mirelman A, Mitsui J, Mizuta I, Nicoletti G, Oliveira C, Ottman R, Orr-Urtreger A, Pereira LV, Quattrone A, Rogaeva E, Rolfs A, Rosenbaum H, Rozenberg R, Samii A, Samaddar T, 
Schulte C, Sharma M, Singleton A, Spitz M, Tan EK, Tayebi N, Toda T, Troiano AR, Tsuji S, Wittstock M, Wolfsberg TG, Wu YR, Zabetian CP, Zhao Y, Ziegler SG. Multicenter analysis of glucocerebrosidase mutations in Parkinson's disease. N Engl J Med. 2009;361(17):1651-61.

105. McNeill A, Duran R, Hughes DA, Mehta A, Schapira AHV. A clinical and family history study of Parkinson's disease in heterozygous glucocerebrosidase mutation carriers. J Neurol Neurosurg. Psychiatry. 2012; 83(8):853-4.

106. Bultron G, Kacena K, Pearson D, Boxer M, Yang R, Sathe S, Pastores G, Mistry PK. The risk of Parkinson's disease in type 1 Gaucher disease. J Inherit Metab Dis. 2010;33(2):167-73. https://doi.org/10.1007/s10545-010-9055-0.

107. Zhang Y, Shu L, Zhou X, Pan H, Xu Q, Guo J, et al. A meta-analysis of GBA -related clinical symptoms in Parkinson's disease. Parkinsons Dis. 2018. Available from: /pmc/articles/PMC6180987/?report=abstract. [cited 2020 Aug 28].

108. Ryan E, Seehra G, Sharma P, Sidransky E. GBA1 -associated parkinsonism: new insights and therapeutic opportunities. Curr Opin Neurol. 2019;32(4): 589-96. https://doi.org/10.1097/WCO.0000000000000715.

109. Biegstraaten M, van Schaik IN, Aerts JM, Langeveld M, Mannens MM, Bour LJ, Sidransky E, Tayebi N, Fitzgibbon E, Hollak CE. A monozygotic twin pair with highly discordant Gaucher phenotypes. Blood Cells Mol Dis. 2011;46(1):39-41.

110. Lachmann RH, Grant IR, Halsall D, Cox TM. Twin pairs showing discordance of phenotype in adult Gaucher's disease. QJM - Mon. J. Assoc. Physicians. 2004;97(4):199-204.

111. Woodard CM, Campos BA, Kuo SH, Nirenberg MJ, Nestor MW, Zimmer M, Mosharov EV, Sulzer D, Zhou H, Paull D, Clark L, Schadt EE, Sardi SP, Rubin L, Eggan K, Brock M, Lipnick S, Rao M, Chang S, Li A, Noggle SA. IPSC-derived dopamine neurons reveal differences between monozygotic twins discordant for parkinson's disease. Cell Rep. 2014;9(4):1173-82. https://doi. org/10.1016/j.celrep.2014.10.023.

112. Chiasserini D, Paciotti S, Eusebi P, Persichetti E, Tasegian A, Kurzawa-Akanbi M, Chinnery PF, Morris CM, Calabresi P, Parnetti L, Beccari T. Selective loss of glucocerebrosidase activity in sporadic Parkinson's disease and dementia with Lewy bodies. Mol Neurodegener. 2015;10:15. Available from: http://www. molecularneurodegeneration.com/content/10/1/15. [cited 2020 Aug 28].

113. Parnetti L, Paciotti S, Eusebi P, Dardis A, Zampieri S, Chiasserini D, Tasegian A, Tambasco N, Bembi B, Calabresi P, Beccari T. Cerebrospinal fluid $\beta$ glucocerebrosidase activity is reduced in parkinson's disease patients. Mov Disord. 2017;32(10):1423-31.

114. Gan-Or Z, Liong C, Alcalay RN. GBA-associated Parkinson's disease and other synucleinopathies. Curr Neurol Neurosci Rep. 2017. Available from: https:// pubmed.ncbi.nlm.nih.gov/29884970/. [cited 2020 Aug 28].

115. Behl T, Kaur G, Fratila O, Buhas C, Judea-Pusta CT, Negrut N, Bustea C, Bungau S. Cross-talks among GBA mutations, glucocerebrosidase, and asynuclein in GBA-associated Parkinson's disease and their targeted therapeutic approaches: a comprehensive review. Transl Neurodegener. 2021;10(1):4

116. Robak LA, Jansen IE, Van Rooij J, Uitterlinden AG, Kraaij R, Jankovic J, et al. Excessive burden of lysosomal storage disorder gene variants in Parkinson's disease. Brain. 2017;140(12):3191-203. https://doi.org/10.1093/brain/awx285.

117. Mazzulli JR, XU Y, Sun Y, Knight AL, Mclean PJ, Caldwell GA, et al. Gaucher disease Glucocerebrosidase and a -synuclein form a bidirectional pathogenic loop in Synucleinopathies; 2011. p. 37-52.

118. Schöndorf DC, Aureli M, McAllister FE, Hindley CJ, Mayer F, Schmid B, et al. IPSC-derived neurons from GBA1-associated Parkinson's disease patients show autophagic defects and impaired calcium homeostasis. Nat Commun. 2014;5(1). https://doi.org/10.1038/ncomms5028.

119. Aflaki E, Borger DK, Moaven N, Stubblefield BK, Rogers SA, Patnaik S, Schoenen FJ, Westbroek W, Zheng W, Sullivan P, Fujiwara H, Sidhu R, Khaliq ZM, Lopez GJ, Goldstein DS, Ory DS, Marugan J, Sidransky E. A new glucocerebrosidase chaperone reduces a-synuclein and glycolipid levels in iPSC-derived dopaminergic neurons from patients with Gaucher disease and parkinsonism. J. Neurosci. 2016;36(28):7441-52.

120. Kim S, Yun SP, Lee S, Umanah GE, Bandaru WR, Yin X, Rhee P, Karuppagounder SS, Kwon SH, Lee H, Mao X, Kim D, Pandey A, Lee G, Dawson VL, Dawson TM, Ko HS. GBA1 deficiency negatively affects physiological a-synuclein tetramers and related multimers. Proc Natl Acad Sci U S A. 2018;115(4):798-803.

121. Fernandes HJR, Hartfield EM, Christian HC, Emmanoulidou E, Zheng $Y$, Booth H, Bogetofte H, Lang C, Ryan BJ, Sardi SP, Badger J, Vowles J, Evetts S, Tofaris GK, Vekrellis K, Talbot K, Hu MT, James W, Cowley SA, Wade-Martins R. ER stress and autophagic perturbations lead to elevated extracellular a- synuclein in GBA-N370S Parkinson's iPSC-derived dopamine neurons. Stem Cell Rep. 2016;6(3):342-56. https://doi.org/10.1016/j.stemcr.2016.01.013.

122. Barkhuizen M, Anderson DG, Grobler AF. Advances in GBA-associated Parkinson's disease - pathology, presentation and therapies. Neurochem Int. 2016;93:6-25. https://doi.org/10.1016/..neuint.2015.12.004.

123. Taguchi YV, Liu J, Ruan J, Pacheco J, Zhang X, Abbasi J, Keutzer J, Mistry PK, Chandra SS. Glucosylsphingosine promotes a-synuclein pathology in mutant GBA-associated parkinson's disease. J Neurosci. 2017;37(40):9617-31. https://doi.org/10.1523/JNEUROSCl.1525-17.2017.

124. Schöndorf DC, Ivanyuk D, Baden P, Sanchez-Martinez A, De Cicco S, Yu C, et al. The NAD+ precursor nicotinamide riboside rescues mitochondrial defects and neuronal loss in iPSC and fly models of Parkinson's disease. Cell Rep. 2018;23(10):2976-88.

125. Sun Y, Florer J, Mayhew CN, Jia Z, Zhao Z, Xu K, Ran H, Liou B, Zhang W, Setchell KD, Gu J, Grabowski GA. Properties of neurons derived from induced pluripotent stem cells of Gaucher disease type 2 patient fibroblasts: potential role in neuropathology. PLoS One. 2015;10(3):e0118771.

126. Mazzulli JR, Xu YH, Sun Y, Knight AL, McLean PJ, Caldwell GA, Sidransky E, Grabowski GA, Krainc D. Gaucher disease glucocerebrosidase and asynuclein form a bidirectional pathogenic loop in synucleinopathies. Cell. 2011;146(1):37-52.

127. Mazzulli JR, Zunke F, Tsunemi T, Toker NJ, Jeon S, Burbulla LF, Patnaik $S$, Sidransky E, Marugan JJ, Sue CM, Krainc D. Activation of $\beta$ glucocerebrosidase reduces pathological a-synuclein and restores lysosomal function in Parkinson's patient midbrain neurons. J. Neurosci. 2016;36(29): $7693-06$.

128. Cahoy JD, Emery B, Kaushal A, Foo LC, Zamanian JL, Christopherson KS, Xing Y, Lubischer JL, Krieg PA, Krupenko SA, Thompson WJ, Barres BA. A transcriptome database for astrocytes, neurons, and oligodendrocytes: a new resource for understanding brain development and function. J Neurosci. 2008;28(1):264-78. https://doi.org/10.1523/JNEUROSCl.4178-07.2008.

129. Zhang Y, Sloan SA, Clarke LE, Caneda C, Plaza CA, Blumenthal PD, et al. Purification and characterization of progenitor and mature human astrocytes reveals transcriptional and functional differences with mouse. Neuron. 2016;89(1):37-53.

130. Osellame LD, Rahim AA, Hargreaves IP, Gegg ME, Richard-Londt A, Brandner $\mathrm{S}$, et al. Mitochondria and quality control defects in a mouse model of gaucher disease - links to Parkinson's disease. Cell Metab. 2013;17:941-53. https://doi.org/10.1016/j.cmet.2013.04.014.

131. Sanyal A, DeAndrade MP, Novis HS, Lin S, Chang J, Lengacher N, et al. Lysosome and inflammatory defects in GBA1 -mutant astrocytes are normalized by LRRK2 inhibition. Mov Disord. 2020;35(5):760-73. Available from: https://onlinelibrary.wiley.com/doi/abs/10.1002/mds.27994.

132. Aflaki E, Stubblefield BK, McGlinchey RP, McMahon B, Ory DS, Sidransky E. A characterization of Gaucher iPS-derived astrocytes: potential implications for Parkinson's disease. Neurobiol Dis. 2020;134:104647. https://doi.org/10.1016/ j.nbd.2019.104647.

133. Blauwendraat C, Reed X, Krohn L, Heilbron K, Bandres-Ciga S, Tan M, Gibbs JR, Hernandez DG, Kumaran R, Langston R, Bonet-Ponce L, Alcalay RN, Hassin-Baer S, Greenbaum L, Iwaki H, Leonard HL, Grenn FP, Ruskey JA, Sabir M, Ahmed S, Makarious MB, Pihlstrøm L, Toft M, van Hilten JJ, Marinus J, Schulte C, Brockmann K, Sharma M, Siitonen A, Majamaa K, Eerola-Rautio J, Tienari PJ, The 23andMe Research Team, Pantelyat A, Hillis AE, Dawson TM, Rosenthal LS, Albert MS, Resnick SM, Ferrucci L, Morris CM, Pletnikova O, Troncoso J, Grosset D, Lesage S, Corvol JC, Brice A, Noyce AJ, Masliah E, Wood N, Hardy J, Shulman LM, Jankovic J, Shulman JM, Heutink P, Gasser T, Cannon P, Scholz SW, Morris H, Cookson MR, Nalls MA, Gan-Or Z, Singleton AB. Genetic modifiers of risk and age at onset in GBA associated Parkinson's disease and Lewy body dementia. Brain. 2020;143(1):234-48. https://doi. org/10.1093/brain/awz350.

134. Gasperini M, Hill AJ, McFaline-Figueroa JL, Martin B, Kim S, Zhang MD, et al. A genome-wide framework for mapping gene regulation via cellular genetic screens. Cell. 2019;176:377-390.e19.

135. Feigin VL, Krishnamurthi R V., Theadom AM, Abajobir AA, Mishra SR, Ahmed $M B$, et al. Global, regional, and national burden of neurological disorders during 1990-2015: a systematic analysis for the Global Burden of Disease Study 2015. Lancet Neurol. 2017;16(11):877-97. https://doi.org/10.1016/S14 74-4422(17)30299-5.

136. Saxena S, Caroni P. Selective neuronal vulnerability in neurodegenerative diseases: from stressor thresholds to degeneration. Neuron. 2011;71:35-48. https://doi.org/10.1016/j.neuron.2011.06.031. 
137. Soto C, Pritzkow S. Protein misfolding, aggregation, and conformational strains in neurodegenerative diseases. Nat Neurosci. 2018;21:1332-40 Available from: http:/www.nature.com/articles/s41593-018-0235-9. [cited 2020 Aug 4].

138. Fu H, Hardy J, Duff KE. Selective vulnerability in neurodegenerative diseases. Nat Neurosci. 2018;21(10):1350-8. https://doi.org/10.1038/s41593-0180221-2.

139. Skovronsky DM, Lee VMY, Trojanowski JQ. Neurodegenerative diseases: new concepts of pathogenesis and their therapeutic implications. Annu Rev Pathol. 2006:151-70 Available from: https://pubmed.ncbi.nlm.nih.gov/1803 9111/. [cited 2020 Aug 4].

140. Dugger BN, Dickson DW. Pathology of neurodegenerative diseases. Cold Spring Harb. p. 10-8. Available from: https://pubmed.ncbi.nlm.nih.gov/292 75161\%. [cited 2020 Aug 4].

141. Kurtishi A, Rosen B, Patil KS, Alves GW, Møller SG. Cellular proteostasis in neurodegeneration Mol Neurobiol. 2019. p. 3676-89. Available from: https:// pubmed.ncbi.nlm.nih.gov/30182337/. [cited 2020 Aug 4].

142. Pacitti D, Privolizzi R, Bax BE. Organs to cells and cells to organoids: the evolution of in vitro central nervous system modelling Front Cell. 2019. p. 129. Available from: www.frontiersin.org. [cited 2020 Sep 7].

143. Grenier K, Kao J, Diamandis P. Three-dimensional modeling of human neurodegeneration: brain organoids coming of age Mol Psychiatry 2020. p. 254-74. Available from: https://www.nature.com/articles/s41380-019-0500-7. [cited 2020 Sep 7].

144. Sloan SA, Andersen J, Pașca AM, Birey F, Pașca SP. Generation and assembly of human brain region-specific three-dimensional cultures. Nat Protoc 2018;13:2062-85 Available from: /pmc/articles/PMC6597009/?report= abstract. [cited 2020 Sep 7].

145. Han I, You Y, Kordower JH, Brady ST, Morfini GA. Differential vulnerability of neurons in Huntington's disease: the role of cell type-specific features. J Neurochem. 2010. https://doi.org/10.1111/j.1471-4159.2010.06672.x.

146. Trinh J, Zeldenrust FMJ, Huang J, Kasten M, Schaake S, Petkovic S, et al. Genotype-phenotype relations for the Parkinson's disease genes SNCA, LRRK2, VPS35: MDSGene systematic review Mov Disord. 2018. p. 185770. Available from: https://pubmed.ncbi.n/m.nih.gov/30357936/. [cited 2020 Aug 29].

\section{Publisher's Note}

Springer Nature remains neutral with regard to jurisdictional claims in published maps and institutional affiliations. 